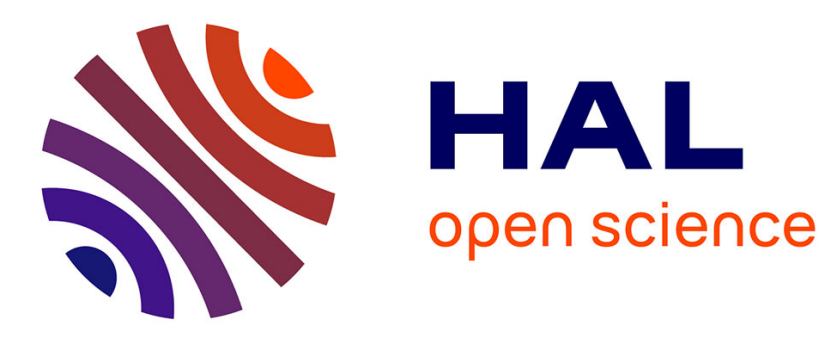

\title{
New PEMFC behaviour law
}

M. Hinaje, W. Kaewmanee, S. Raël, B. Davat

\section{To cite this version:}

M. Hinaje, W. Kaewmanee, S. Raël, B. Davat. New PEMFC behaviour law. European Physical Journal: Applied Physics, 2011, 54 (2), 10.1051/epjap/2010151 . hal-00699041

\section{HAL Id: hal-00699041 \\ https://hal.science/hal-00699041}

Submitted on 19 May 2012

HAL is a multi-disciplinary open access archive for the deposit and dissemination of scientific research documents, whether they are published or not. The documents may come from teaching and research institutions in France or abroad, or from public or private research centers.
L'archive ouverte pluridisciplinaire HAL, est destinée au dépôt et à la diffusion de documents scientifiques de niveau recherche, publiés ou non, émanant des établissements d'enseignement et de recherche français ou étrangers, des laboratoires publics ou privés. 


\title{
New PEMFC behaviour law
}

\author{
M. Hinaje*, W. Kaewmanee, S. Raël, and B. Davat \\ GREEN - Institut National Polytechnique de Lorraine \\ 2, Avenue de la Forêt de Haye \\ 54516 Vandœuvre-lès-Nancy, France \\ * Corresponding Author melika.hinaje@ensem.inpl-nancy.fr \\ Fax number: +33383595653
}

\begin{abstract}
This paper presents a new steady state model which contains fewer polarisation curve fitting parameters compared to other semi-empirical models. The established model is also defined at no load operation and can be fitted perfectly to the static polarisation curve for a wide range of cell currents. The model links the fuel cell voltage to the current by a simple function to which various useful derivative laws can be applied. As a result, many analytical expressions, for example, polarisation resistance or power density, can be evaluated directly from the model.
\end{abstract}

Keywords: Proton exchange membrane fuel cell; steady state model; polarisation curve; semi-empirical model; polarisation resistance.

\section{Introduction}

Polymer electrolyte membrane fuel cells (PEMFCs) are the attractive solution for zero emission energy productions. They are the promising alternative sources for stationary and transported applications. To improve the efficiency of the fuel cell system, designers need a simple but accurate model of the fuel cell. Unfortunately, the mentioned model is not yet existence.

The straightforward method to create the fuel cell model is to develop the physics model that is to say coupled partial differential equations model. However, the fuel cell system is usually incorporated with many auxiliary systems such as compressors, cooling system and flow control valves, so that, the physics model, which is constructed from physics, electrochemical and thermodynamic laws of each system element, will be very complicated and difficult to use.

The empirical or semi-empirical fuel cell models are the other option to the designer. This kind of model is usually a simple mathematical formula with some curve fitting parameters which form a relationship between the interested variables, in this case the terminal voltage and current of the fuel cell. The drawback of this model is that it usually contains the logarithmic function which makes the model undefined at zero current operation.

This paper presents a new empirical model of PEMFC. The proposed model contains only two curve fitting parameters which is less than the usual empirical (or semi-empirical) models may have. Further more, there is no logarithmic function in the model, so that, it is continuous and differentiable.

\section{The fuel cell models}

At present, there are three main types of PEMFC models which are the mass transport, the empirical equivalent electrical circuit model and the empirical mathematic model. 


\subsection{Mass transport model}

This kind of model describes entire physical phenomena of electrochemical reactions, such as the transports of gases, water, protons and current, that lead to the relationships amongst fuel cell voltages, currents, temperature, and material parameters [1]-[3]. Several aspects are involved in this kind of model, for example, multi-species diffusions through gas diffusion layers, electrochemical reactions in the activation layers, and water and protons transport through the membrane. All these phenomena are strongly coupled and thermally dependent [4]. Some parameters, for example the current density, are space dependent which make them not just difficult to solve but also require a high computational cost. Moreover, this detailed model contains many adjustable parameters.

This kind of model is necessary to predict and analyse the static or transient behaviour of a fuel cell, or just a part of them by means of computer simulations in different running conditions. However, the model is very difficult to understand and is not well suited for control applications.

\subsection{Empirical equivalent electrical circuit model}

The empirical model is a model that has no solid link between the model and the physical system. The model always needs an experimental result from the real system to adjust the model parameters. The circuit model is one form of the empirical model of the PEMFC. The circuit in Fig. 2 is a common and practical circuit model for a PEMFC [5]-[7]. It consists of three resistors where the $r_{m}$ represents the membrane resistance, $r_{a}$ and $r_{c}$ stand for anode and cathode charge transfer resistance due to the hydrogen oxidation and oxygen reduction, respectively. $\mathrm{C}_{\mathrm{dl}, \mathrm{a}}$ and $\mathrm{C}_{\mathrm{dl}, \mathrm{c}}$ are the double layer capacitances at the electrode/membrane interfaces. Finally, $Z_{\mathrm{w}, \mathrm{a}}$ and $\mathrm{Z}_{\mathrm{w}, \mathrm{c}}$ are the diffusion impedances of the gas diffusion layer in the anode and the cathode side, respectively. Normally, these parameters are identified by using an electrochemical impedance spectroscopy (EIS) [8].

The feature of the model is the low computational cost and its use in control applications. However, as shown in figure 1, there ares a lot of parameter to estimate.

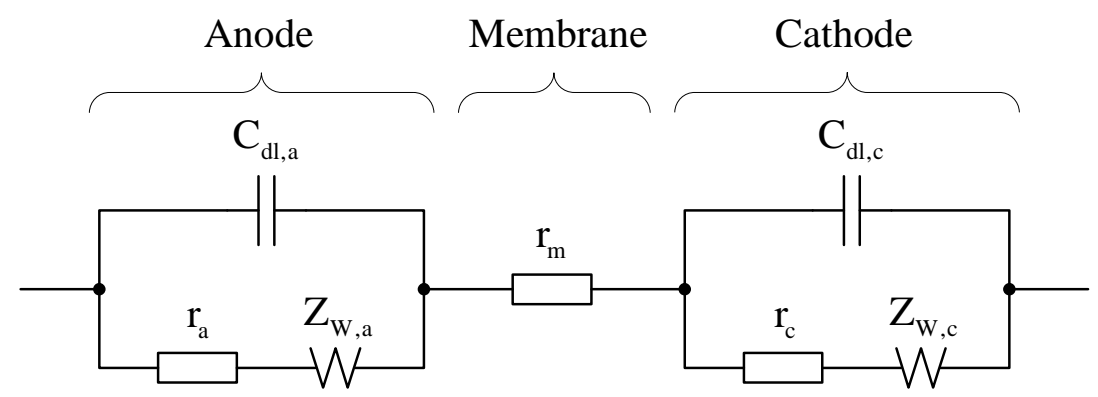

Fig. 1. An Equivalent circuit of a PEM fuel cell

\subsection{Empirical mathematic model}

Some of them are based on a strong, though simplified, physical description of the MEA behaviour [9] [10]. The advantage is that they allow the experimental determination of important parameters governing the electrode processes. In this sense this type of model is used to confirm the physical interpretation of PEM single cell behaviour in contrast to a simple prediction of a polarisation curve. However, contrary to our model, those semiempirical models are typically intended for single PEMFC and not for stacks. 
Other models are quite simple compared to the pure theoretical models previously described. The empirical equation is used to establish the relation between voltage and current of the fuel cell [11], [12]. For example, one of the most preferred models is:

$$
\begin{aligned}
& \mathrm{U}=\mathrm{U}_{\mathrm{o}}-\mathrm{b} \ln (\mathrm{I})-\mathrm{RI} \\
& \mathrm{U}_{\mathrm{O}}=\mathrm{U}_{\mathrm{r}}-\mathrm{b} \ln \left(\mathrm{I}_{\mathrm{O}}\right)
\end{aligned}
$$

where $U_{r}$ is the reversible cell voltage, $b$ is the Tafel slope, and $I_{o}$ is the exchange current density and $\mathrm{R}$ is the ohmic resistance.

Kim et al. [13] proposed the improved version of this expression by adding a term that would correct the observed difference between the voltages computed from (1) and the measured one. This difference has been fixed with the following exponential function:

$$
\Delta U=m \exp (n I)
$$

where $\mathrm{m}$ and $\mathrm{n}$ are constant. Then, (1) can be rewritten as:

$$
U=U_{o}-b \ln (I)-R I-m \exp (n I)
$$

This kind of model is quite accurate in a wide operating range. However, as it can be seen in (4), the relation is undefined for no-load operations (i.e. $\mathrm{I}=0$ ) and there are five parameters that have to be determined.

\section{The proposed static model}

The new static model, which was established in this work, is simpler than those described above as it has only two parameters to be determined. Moreover, this model is defined at $\mathrm{I}=0$ at atmospheric pressure and for a given temperature stack, it is continuous, differentiable and simple, as follows:

$$
U=\frac{U_{o}}{1+a I^{\alpha}}
$$

where $U_{o}$ is the open circuit voltage (OCV) and $\mathrm{I}$ is the fuel cell stack current. As seen in (5), $\mathrm{aI}^{\alpha}$ has no unit, this implies that the parameter "a" can be expressed as $\mathrm{I}_{\mathrm{h}}^{-\alpha}$, where $\mathrm{I}_{\mathrm{h}}$ is equivalent to an electrical current and its unit is cancelled with I. Then, (5) can be rewritten as:

$$
U=\frac{U_{o}}{1+\left(\frac{I}{I_{h}}\right)^{\alpha}}
$$

where $\alpha$ and $\mathrm{I}_{\mathrm{h}}$ are the only two parameters to be determined.

We can try to link the parameter $I_{h}$ to a fuel cell characteristic parameter, for instance to the open circuit voltage. By rearranging and applying the logarithmic function on both sides, (6) can be rewritten as:

$$
\alpha \ln \left(\frac{I}{I_{h}}\right)=\ln \left(\frac{U_{0}-U}{U}\right)
$$


From (7), we can deduce that the current $I_{h}$ is equal to $I$ at $U=U_{O} / 2$. However, this is just a theoretical value because a healthy stack cannot safely reach this static operating point. By the experimental results and using the non-integer power law function, the polarisation curve is fitted by a least squares method.

As mentioned, the other useful behaviour laws can be derived from the proposed model, for instance the function of the current-electric power curve and the current-polarisation resistance curve will be shown here.

Since the electric power of the fuel cell is simply the product of the voltage and the current, the function of the current-power derived form the model is:

$$
P=\frac{U_{o} I}{1+\left(\frac{I}{I_{h}}\right)^{\alpha}}
$$

The last example is the derivation of the current-polarisation resistance curve.

Generally, the fuel cell voltage, $U$, can be expressed as a function of the steady state open circuit voltage $\left(U_{0}\right)$ where the voltage drops due to the cathode and anode activations $\left(\eta_{\mathrm{c}}, \eta_{\mathrm{a}}\right)$ and the membrane $\left(\eta_{m}\right)$ as follow:

$$
U=U_{o}-\eta_{a}-\eta_{c}-\eta_{m}
$$

Each term of the voltage drop can be considered as a result from the parasitic resistance of each part.

The fuel cell resistance is a sum of those resistances [14] and the steady state fuel cell voltage can be rewritten as:

$$
U=U_{o}-R_{p} I
$$

This resistance is usually measured using the EIS method. The analytical expression of the fuel cell in (6) enables us to evaluate $\mathrm{R}_{\mathrm{p}}$ in (10) as follow:

$$
R_{p}=\frac{U_{o}}{I} \frac{\left(\frac{I}{I_{h}}\right)^{\alpha}}{1+\left(\frac{I}{I_{h}}\right)^{\alpha}}
$$

\section{Experimental setup and results}

For model verification, the experiments are performed on a sixteen cell stack. The stack temperature is assumed to be homogenous through the system. The details of the experimental set up is shown in Fig. 2. The parameters are given in Table I. Only the inlet air is humidified. 


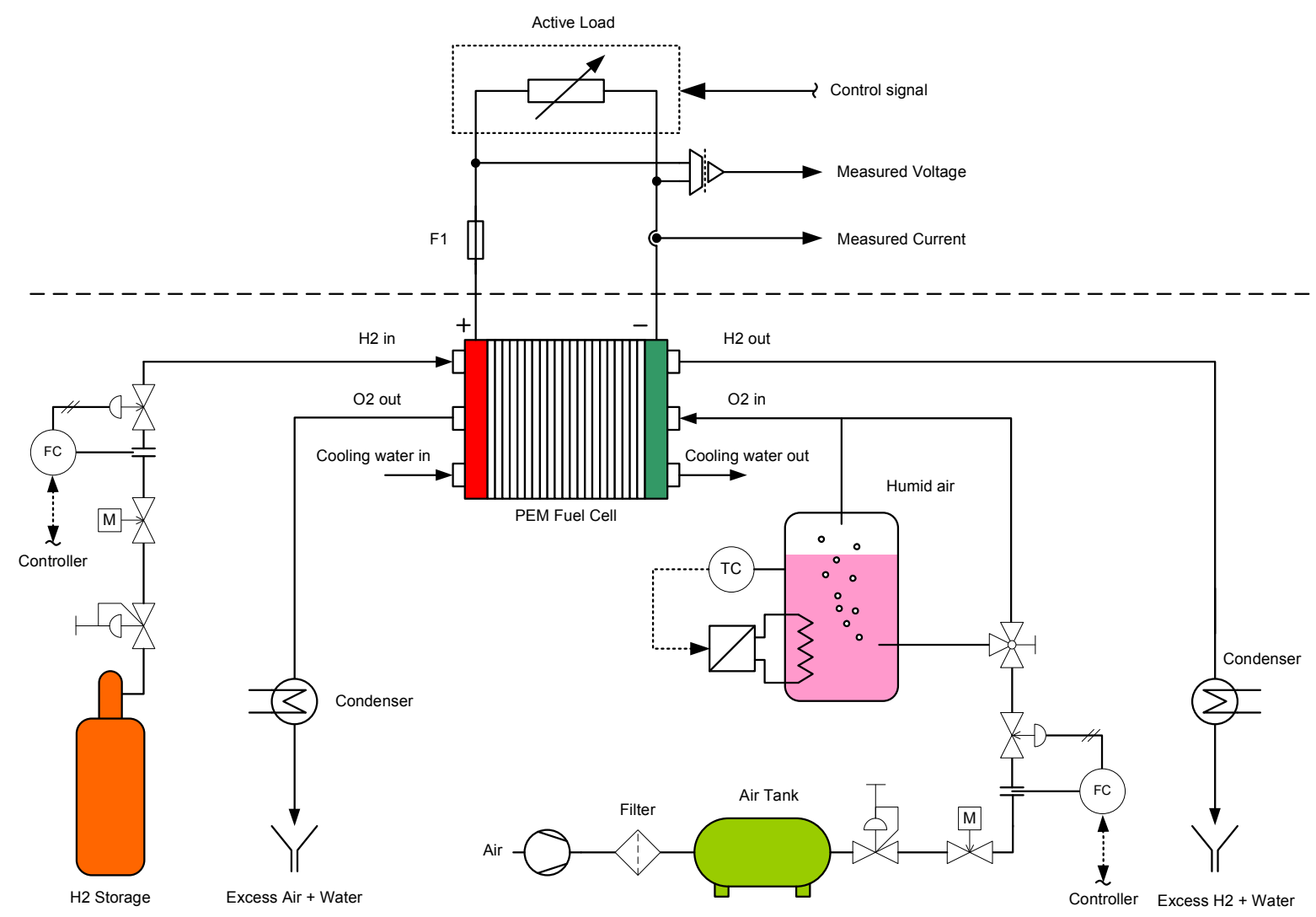

Fig. 2. PEMFC test bench

Table I

Fuel Cell Parameters

\begin{tabular}{|l|l|}
\hline Fuel cell type & Proton exchange membrane \\
\hline Power & $500 \mathrm{~W}$ \\
\hline Number of cells & 16 \\
\hline Active area & $100 \mathrm{~cm}^{2}$ \\
\hline Anode operating pressure & $1 \mathrm{~atm}$ \\
\hline Cathode operating pressure & $1 \mathrm{~atm}$ \\
\hline Stack temperature & $60{ }^{\circ} \mathrm{C}$ \\
\hline RHa & $0 \%$ \\
\hline RHc & $37 \%$ and $63 \%$ \\
\hline
\end{tabular}

Table II

Model parameters for different cathode relative humidity

\begin{tabular}{|c|c|c|}
\hline RHc & $37 \%$ & $63 \%$ \\
\hline $\mathrm{I}_{\mathrm{h}}[\mathrm{A}]$ & 449.7 & 483.2 \\
\hline$\alpha$ & 0.338 & 0.350 \\
\hline
\end{tabular}

A comparison between the proposed model in (6) and the experimental result for two different humidification conditions has shown in Fig. 3. The values of $I_{h}$ and $\alpha$ are obtained using a least squares method and given in Table II. It should be noted that the coefficients $\mathrm{I}_{\mathrm{h}}$ and $\alpha$ depend on the humidification of the inlet gas. 


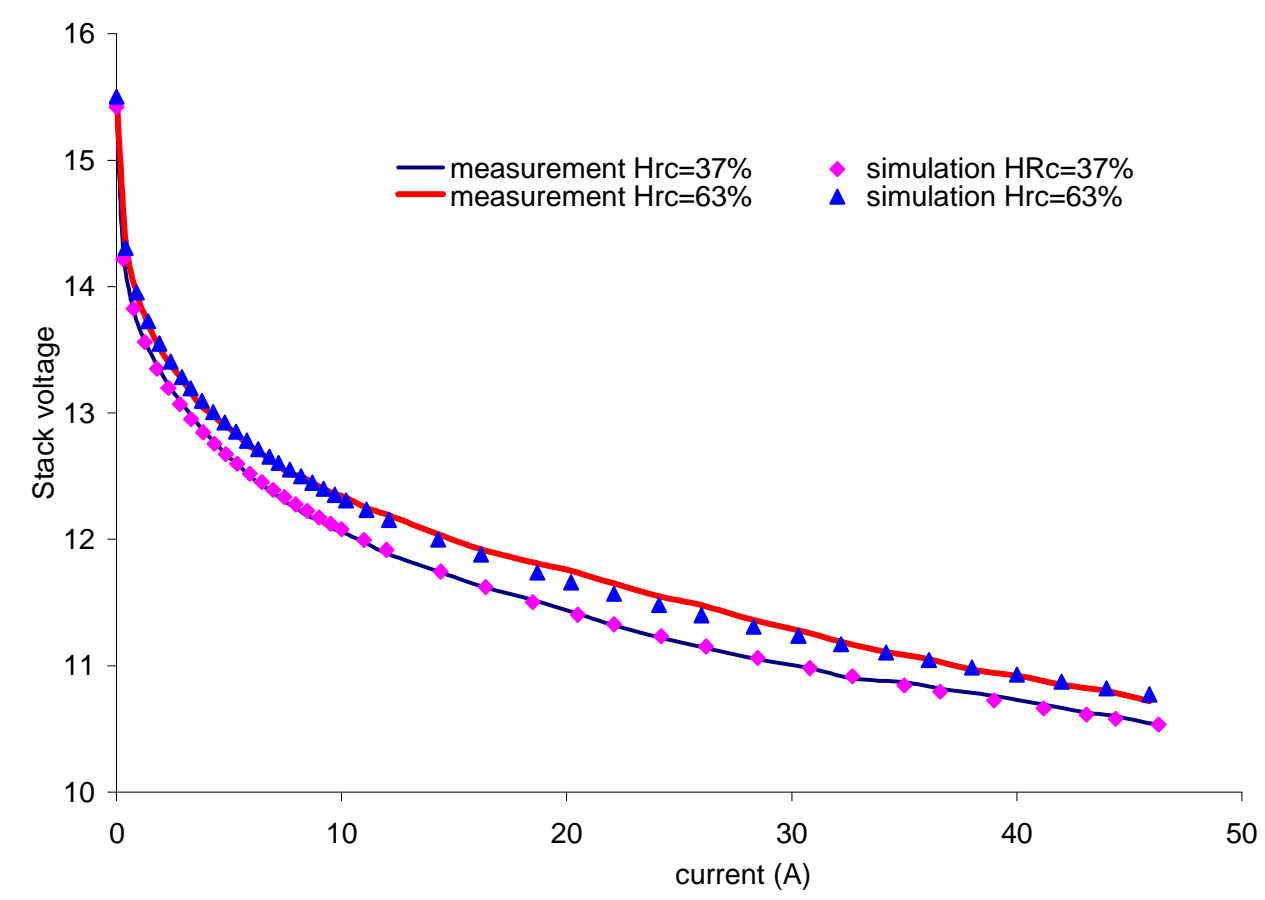

Fig. 3. Comparison between the polarisation curves from (6) and the experimental results

For the current-power characteristic function in (8), the function provides an accurate result compared to the experimental curves as shown in Fig. 4. Since the mass transport limitation does not appear under the normal fuel cell operation, the power curve under normal operating range is roughly a linear function of the current.

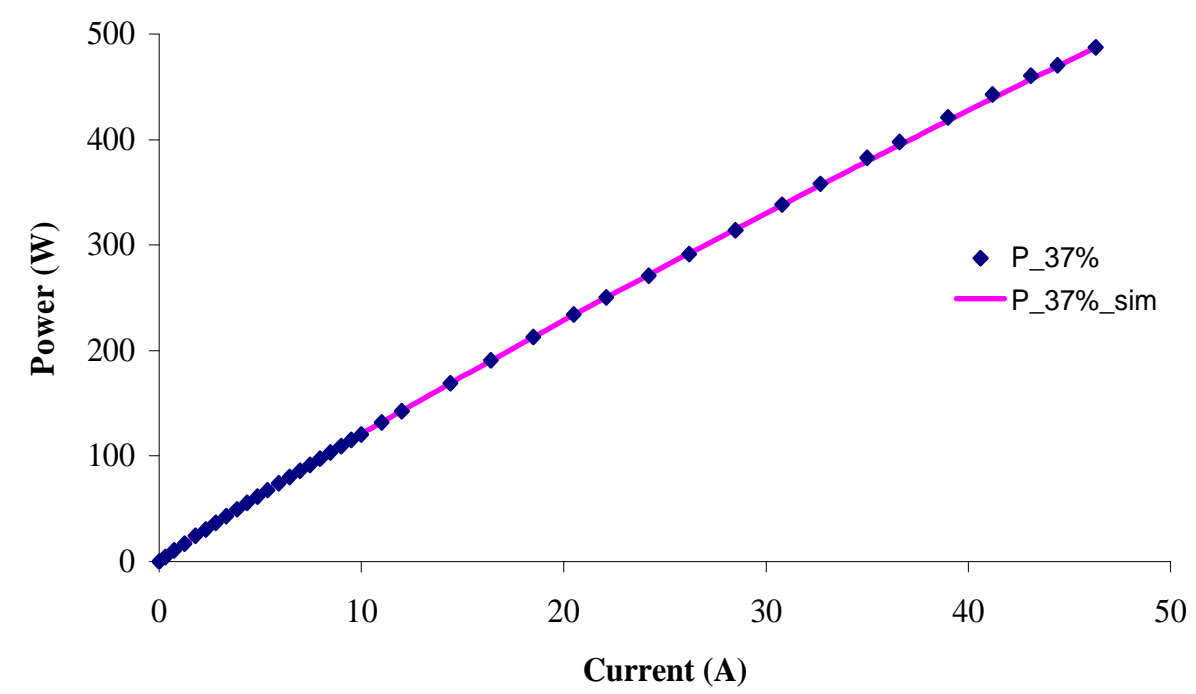

Fig. 4. Comparison between the current-power curves from (8) and the experimental results

The evaluated polarisation resistances versus current of the fuel cell at different relative humidity of the inlet air are plotted in Fig. 5. The computed polarisation resistances from (11) are definitely corresponding to the ones obtained experimentally. 


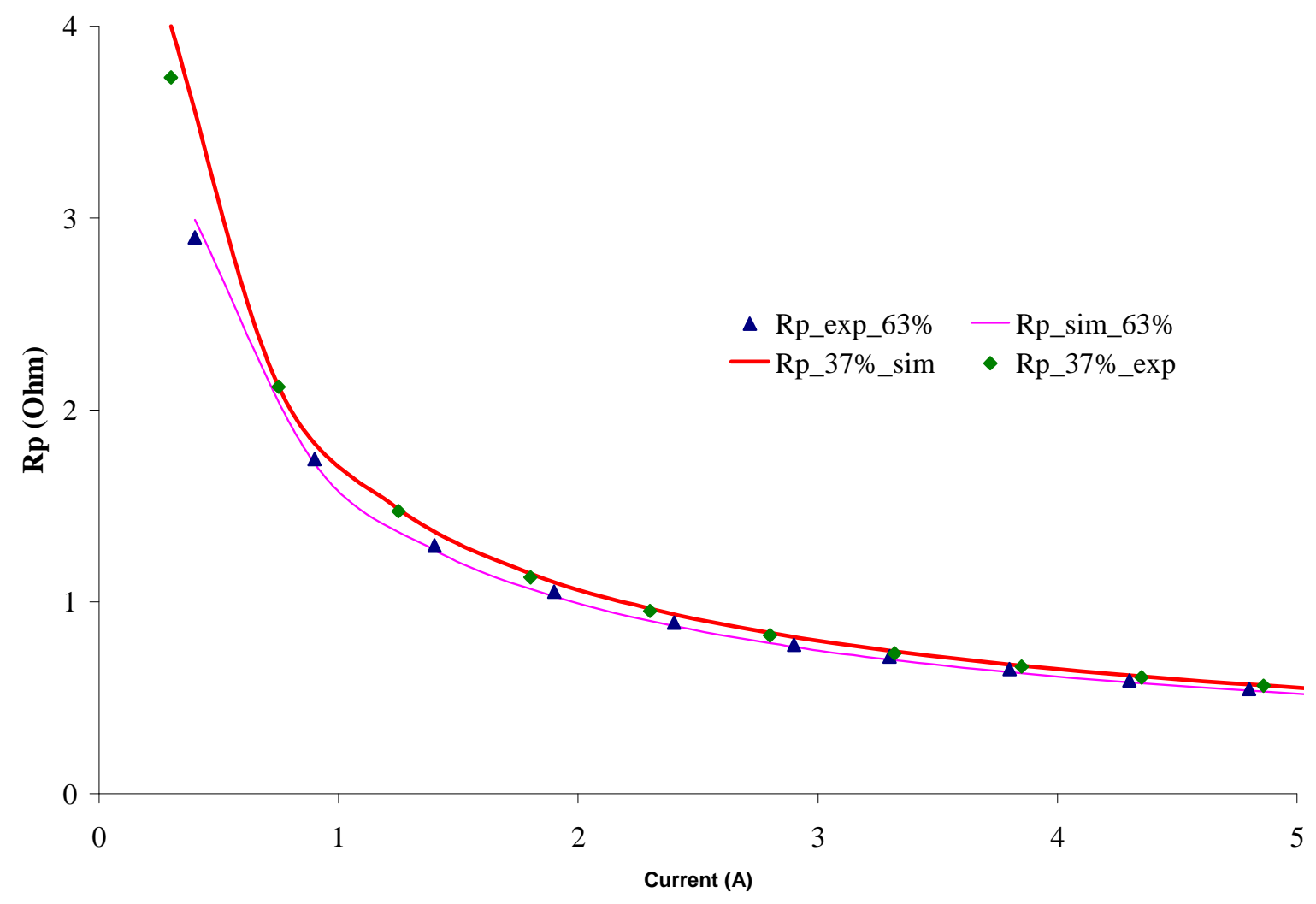

Fig. 5. Measured and computed polarisation resistances.

Therefore, the model is in good agreement with experimental results.

Since, the parameters are determined under constant and homogeneous temperature and pressures, several additional experiments are needed when temperature or pressure are changed.

\section{Conclusion}

In this work, a new PEMFC steady state model has been established. This model contains less fitting parameters than the usual ones, but presents many advantages for control application. The important property of the model is the validity at open circuit operation, in contrast to the other model that is undefined when the current approaches to zero. Further more, the model is differentiable which is preferred by electrical engineers. Various analytical expressions can be derived from the model, the expressions of current-electrical power and current-polarisation resistance are derived here as examples. The curve of the cell resistance from the expression is in accordance with the resistance at the low frequency measured by EIS method without any extrapolation [15]. 


\section{References}

[1] T. E. Springer, T. A. Zawodzinski and S.Gottesfeld, Polymer J. Electrochem. Soc. 138, 8, (1991)

[2] D. M. Bernardi, M. W. Verbrugge, J. Electrochem. Soc. 139, 9, (1992)

[3] S. H. Ge, and B.-L. Yi, Journal of Power Sources 124, (2003).

[4] N. R. Amundson, T.-W. Pan and V. I. Paulsen, AIChE Journal, 49, 4, (2003)

[5] T. E. Springer, T. A. Zawodzinski, M. S Wilson and S. Gottesfeld, J. Electrochem. Soc. 143, (1996)

[6] M. A. Rubio, A. Urquia R. Kuhn, S. Dormido, Journal of Power Sources 183, (2008)

[7] C. Brunetton, A. Moschetto, G. Tina, Electric Power Systems Research 79, (2009)

[8] E. Barsoukov, J. Ross Macdonald, Impedance Spectroscopy: Theory, Experiment, and Applications, (John Wiley \& Sons, 2005)

[9] M. V. Williams, H. Russell Kunz, J. M. Fenton, J. Electrochem. Soc., 152, (2005).

[10] R. F. Mann, John C. Amphlett, M. A.I. Hooper, H. M. Jensen, B. A. Peppley, P. R. Roberge, Journal of Power Sources 86, (2000).

[11] M. G. Santarelli, M. F. Torchio, P. Cochis, Journal of Power Sources 159, (2006)

[12] P. Spinelli, C. Francia, E. P. Ambrosio, M. Lucariello, Journal of Power Sources 178, (2008)

[13] J. Kim, S. Lee, S. Srinivasan and C.E. Chamberlin, J Electrochem Soc 142, (1995)

[14] N. Wagner, Journal of Applied Electrochemistry 32, (2002).

[15] X. Yuan et al., International Journal of Hydrogen Energy 32, (2007) 